\title{
PARASITIC MYOMA AS AN ADNEXAL MASS: UNEXPECTED FINDING AFTER VAGINAL HYSTERECTOMY
}

\author{
Ratko Delić and Vladimir Weber
}

Department of Obstetrics and Gynecology, Celje General Hospital, Celje, Slovenia

\begin{abstract}
SUMMARY - A rare case of parasitic myoma mimicking an adnexal mass in a previously hysterectomized, postmenopausal woman is presented. Two years after vaginal hysterectomy (due to myomas), an asymptomatic right adnexal tumor was noted during regular annual follow up. Ultrasound demonstrated a large 4-5 cm solid mass in the right adnexa, while ovarian cancer biomarkers (CA 125 and HE4) were negative. Intraoperatively, another $3 \mathrm{~cm}$ large solid tumor located above the vaginal cuff was discovered. Both pelvic tumors were excised by laparoscopic surgery. The masses were confirmed by histopathology to be leiomyomas.
\end{abstract}

Key words: Myoma; Adnexal tumors; Hysterectomy, vaginal; Case reports

\section{Introduction}

Benign uterine myomas are the most common pelvic tumor in women ${ }^{1}$. On the contrary, parasitic myomas are a rare benign condition. Although first described by Kelly and Cullen at the beginning of the $20^{\text {th }}$ century, the cause, natural history, and pathologic basis of parasitic myomas are still not clearly understood $^{2}$. Traditionally, parasitic myomas were thought to occur spontaneously as pedunculated subserous myomas lose their uterine blood supply and parasitize to other organs. Probably even more parasitic myomas may be iatrogenically created after surgery, particularly surgery using morcellation techniques. Consequentially, unusual growth patterns and involvement of various anatomic sites may pose serious diagnostic difficulties, even mimicking malignancy.

We present a case of parasitic myoma mimicking an adnexal mass in a previously hysterectomized, postmenopausal woman, successfully diagnosed and treated by laparoscopy.

Correspondence to: Ratko Delic, $M D, P h D$, Department of Obstetrics and Gynecology, Celje General Hospital, Oblakova 5, Celje, 3000 Slovenia

E-mail: rdelic@gmail.com

Received September 23, 2015, accepted February 1, 2016

\section{Case Report}

A 67-year-old Caucasian, asymptomatic female ( $\mathrm{G}$ 3 , P 2) presented to our Department for her annual gynecologic examination. She underwent vaginal hysterectomy without adnexectomy due to multiple uterine myomas in 2013. A $3.5 \mathrm{~cm}$ subserous myoma and $1.5 \mathrm{~cm}$ intramural myoma were demonstrated by ultrasound preoperatively, while histopathology confirmed the diagnosis and reported even more small intramural myomas approximately $1 \mathrm{~cm}$ large. Two years later, transvaginal ultrasound demonstrated a solid right adnexal mass, approximately $4-5 \mathrm{~cm}$ large, without septations or papillary excrescences. There were no ascites in the pelvic cavity.

The patient's serum CA $125(14.4 \mathrm{U} / \mathrm{mL})$ and HE4 (8.1 pmol/L) were within the reference range. Diagnostic laparoscopy demonstrated a $4-5 \mathrm{~cm}$ large, pedunculated, solid tumor in the right ovarian fossa. The right ovary appeared small and atrophic, adjacent to the tumor.

Additionally, another pedunculated, solid, approximately $3 \mathrm{~cm}$ large tumor was discovered above the vaginal cuff.

Macroscopically, the left ovary seemed atrophic and small as well. Laparoscopic bilateral salpingo-oo- 


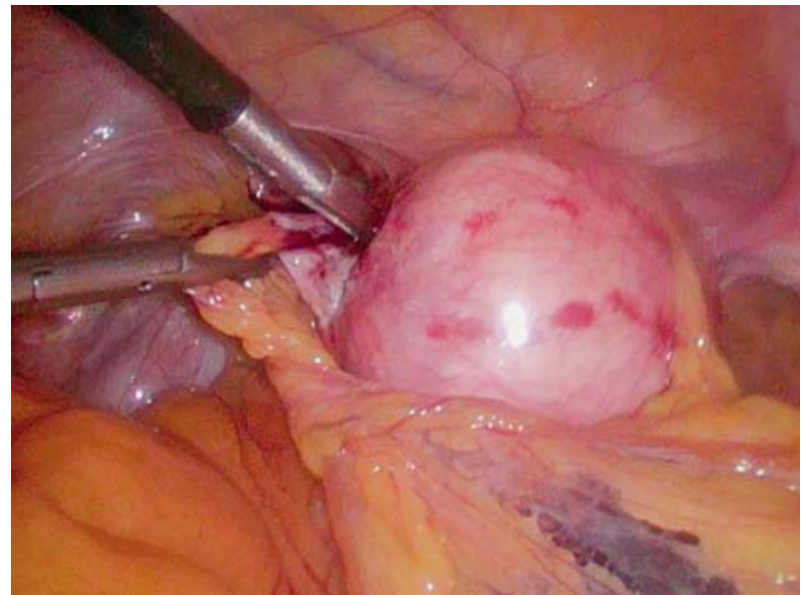

Fig. 1. Laparoscopic myomectomy in second operation: a 4-5 cm solid mass in the right ovarian fossa receiving auxiliary blood supply.

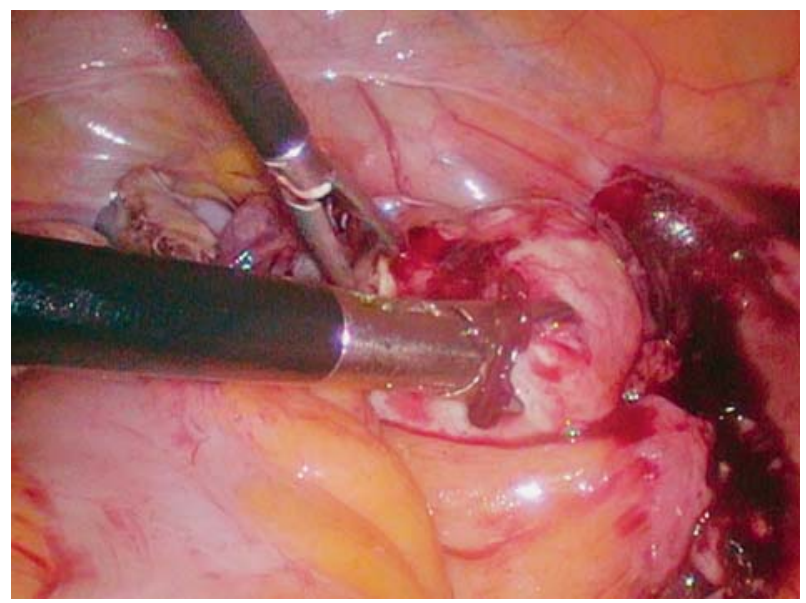

Fig. 2. Another solid mass measuring $3 \mathrm{~cm}$ present above the vaginal cuff.

phorectomy was performed, while both myomas were retrieved by morcellation and the peritoneal cavity was washed with isotonic saline. Histopathologic findings of both tumors were consistent with leiomyoma. However, histologic sections from fallopian tubes and ovaries did not reveal any significant pathology. The patient continued to receive annual follow up after the second surgery.

\section{Discussion}

Uterine myomas (fibroids or leiomyomas) are the most common pelvic tumor in women, whereas para- sitic myomas are exceptionally rare, benign, and may arise at various anatomic sites. The term parasitic myoma has been used to explain a lesion that has become adherent to the surrounding structures, develops an auxiliary blood supply, and loses attachment to the origin. Conventionally, parasitic myomas were thought to be a rare variant of pedunculated subserous myomas that were accidentally separated from the uterus and had become attached to another organ in the abdominal cavity for their blood supply ${ }^{3,4}$.

The increasing number of case reports of parasitic myomas after the use of surgical therapy, especially laparoscopic morcellation, has contributed to the development of an iatrogenic theory ${ }^{3}$. It is assumed that seeding of retained small tissue fragments after morcellation can lead to the development of parasitic myoma in the abdominal cavity.

The major risk factors for the development of parasitic myomas are the presence of uterine myoma and prior laparoscopic hysterectomy or myomectomy with morcellation.

According to the literature, the overall incidence of parasitic myomas after laparoscopic surgery with the use of morcellation is reported to range between $0.12 \%$ and $0.9 \%$, and the incidence of parasitic myomas after laparoscopic myomectomy between $0.2 \%$ and $1.2 \%$. Yet another potential difficulty with laparoscopic power morcellators can be destruction of myometrial tissue through morcellation with an associated risk of malignant dissemination of uterine sarcoma ${ }^{4,7,8}$.

Based on the published case reports, the most likely locations of parasitic myomas are in the areas close to a myomatous uterus. Nevertheless, parasitic myomas may arise at any anatomic sites, making it a diagnostic challenge. Patients may present with symptoms such as abdominal or pelvic pain, dyspareunia, abdominal distension, urinary frequency and constipation. However, a significant proportion of patients are asymptomatic and parasitic myomas are unexpectedly diagnosed during routine examination or another surgical procedure. Their growth pattern may even mimic malignancy and can result in a clinical dilemma, as in our case. In such cases, laparoscopy can be a diagnostic and therapeutic tool of choice.

Concerning the risk factors during postmenopause, it is hypothesized that prolonged exposure to steroid hormones could be a risk factor for the development of parasitic myoma; however, our patient did not take any form of hormone replacement therapy. 
Our aim in this report is to add to the literature the rare possibility of finding parasitic myoma in the postmenopausal patient, years after vaginal hysterectomy.

\section{References}

1. Habek D, Aškamija A. Successful acupuncture treatment of uterine myoma. Acta Clin Croat. 2014;53:487-9.

2. Kelly HA, Cullen TS. Myomata of the Uterus. Philadelphia: WB Saunders; 1909.

3. Kho KA, Nezhat C. Parasitic myomas. Obstet Gynecol. 2009;114:611-5. doi: 10.1097/AOG.0b013e3181b2b09a.

4. Brölmann H, Tanos V, Grimbizis G, Ind T, Philips K, Van Den Bosch T, et al. Options on fibroid morcellation: a literature review. Gynecol Surg. 2015;12:3-15.

5. Cucinella G, Granese R, Calagna G, Somigliana E, Perino A. Parasitic myomas after laparoscopic surgery: an emerging com- plication in the use of morcellator? Description of four cases. Fertil Steril. 2011;96:e90-e6. doi: 10.1016/j.fertnstert.2011. 05.095 .

6. Sinha R, Hegde A, Mahajan C, Dubey N, Sundaram M. Laparoscopic myomectomy: do size, number, and location of the myomas form limiting factors for laparoscopic myomectomy? J Minim Invasive Gynecol. 2008;15:292-300. doi: 10.1016/j. jmig.2008.01.009.

7. U.S. Food and Drug Administration [Internet]. Laparoscopic uterine power morcellation in hysterectomy and myomectomy: FDA safety communication. [Cited 2014 April 17]. Available from: http://www.fda.gov/medicaldevices/safety/alertsandnotices/ucm393576.htm.

8. Beckmann MW, Juhasz-Böss I, Denschlag D, Gaß P, Dimpfl T, Harter P, et al. Surgical methods for the treatment of uterine fibroids - risk of uterine sarcoma and problems of morcellation. Position Paper of the DGGG. Geburtshilfe Frauenheilkd. 2015;75:148-64.

Sažetak

\section{PARAZITSKI MIOM KAO ADNEKSALNI TUMOR: NEOČEKIVANI NALAZ NAKON VAGINALNE HISTEREKTOMIJE}

\section{R. Delić i V. Weber}

Prikazan je rijedak slučaj u kojem parazitski miom oponaša adneksalni tumor u prethodno histerektomizirane, postmenopauzalne žene. Dvije godine nakon vaginalne histerektomije (zbog rastućeg mioma) asimptomatski tumor u predjelu desnih adneksa je uočen tijekom redovitog preventivnog pregleda. Pomoću ultrazvuka prikazan je solidan tumor veličine 4-5 $\mathrm{cm}$ u predjelu desnih adneksa, dok su tumorski biljezi kod ovarijskih neoplazmi (CA 125, HE4) bili negativni. Intraoperacijski je otkriven još jedan solidan tumor veličine oko $3 \mathrm{~cm}$ smješten iznad svoda rodnice. Oba tumora su odstranjena pomoću laparoskopije, pri čemu je patohistološki nalaz potvrdio da se radi o miomima.

Ključne riječi: Miom; Adneksalni tumori; Histerektomija, vaginalna; Prikazi slučaja 